\title{
INTERLABORATORY COMPARISON IN CONTEXT OF INAPPROPRIATE RESULTS OF VOLTAGE THERMAL CONVERTER CALIBRATION
}

\author{
Oleh Velychko, Valentyn Isaiev \\ State Enterprise "All-Ukrainian State Research and Production Center for Standardization, \\ Metrology, Certification and Consumers' Rights Protection”, \\ 4 Metrologichna str., 03143 Kyiv, Ukraine \\ velychko@hotmail.com
}

\begin{abstract}
A b s tra c t: The paper is devoted to the analysis of calibration results of thermoelectric voltage converter obtained by five participants of interlaboratory comparisons which ended in 2017. The analysis is accented on several aspects that led to inadequate deviation of results from the expected values. The attention is focused on the reasons for overestimation of measurement uncertainty reported by one of laboratories and the exceeding of the permissible value of criterion for assessing the competence of another laboratory at one observation point. Two variants of measurement schemes which were used by participants, are analyzed, main uncertainty sources are determined, uncertainty budgets are drawn up. The measurement model for a non-standardized measurement set-up is proposed, taking into account the drift of input and output signals. The logical conclusion of analysis is ascertainment of non-compliance with ISO/IEC 17025 recommendations and sufficient level lack of methodological support for these calibration laboratories.
\end{abstract}

Key words: interlaboratory comparison; voltage thermoconverter; calibration; uncertainty

\section{МЕЃУЛАБОРАТОРИСКА СПОРЕДБА НА НЕСИГУРНОСТА НА РЕЗУЛТАТИ ОД КАЛИБРАЦИЈА НА ТЕРМОЕЛЕКТРИЧЕН КОНВЕРТОР НА НАПОН}

\begin{abstract}
А п с т р а к т: Трудот е посветен на анализа на резултатите од калибрација на термоелектричен конвертор на напон добиени од пет учесници на меѓулабораториски споредби што завршија во 2017 година. Анализата е сосредоточена на неколку аспекти кои доведоа до несоодветно отстапување на резултатите од очекуваните вредности. Вниманието се фокусира на причините за преценување на мерната несигурност пријавена од една од лабораториите и на прекумерната дозволена вредност на критериумот за процена на компетентноста од друга лабораторија во една точка на набљудување. Анализирани се две варијанти на мерни шеми кои беа користени од учесниците, се утврдуваат главните извори на несигурност, изготвени се буџети на несигурност. Предложен е меренмодел за нестандардна мерна шема со земање предвид насока на влезните и излезните сигнали. Логичен заклучок на анализата е утврдувањето на неусогласеноста со препораките ISO/IEC 17025 и недоволна методолошка поддршка за овие лаборатории за калибрација.
\end{abstract}

Клучни зборови: меѓулабораториска споредба; термоконвертор на напон; калибрација; несигурност

\section{INTRODUCTION}

Interlaboratory comparison (ILC) is an obligatory and integral part of the external quality control of the obtained measurement results (MR). The participation in the ILC plays an important role both during calibration laboratory $(\mathrm{CL})$ certification and in assessing its competence.
The international standard ISO/IEC 17043 [1] does not authorize the coordinator to discriminate and limitate participants in the selection of methods and means for carrying up the measurement work. The possibility of losing confidence in the actions of the coordinator, in the consequence of the general, extremely low degree of preparedness of a significant number of participants, is not taken into account too. The problems of a technical nature and 
problems of managing quality in the laboratory, identified in the process of analyzing the MRs of ILC participants, lead to exceeding the admissible values of the criteria for estimating the convergence of results. Especially, non-compliance with recommendations on the choice of method, equipment and the definition of uncertainty sources. The wrong choice of the method may deprive the participant of the opportunity to adequately apply outdated equipment and indicate the result with the minimum uncertainty.

The coordinator takes into account the possibility of using different methods of measuring parameters or characteristics of an object, when making up a program of qualification testing. It is supposed to use a method that is sufficiently valid for the given laboratory and its equipment. Different measurement methods used by the laboratory, regardless of the measured quantity, should be considered as equivalent.

There was ILC in the calibration of a precision thermoconverter in the branch of measurements of the alternative voltage in the range up to $1000 \mathrm{~V}$ during the period from July 2016 to March 2017 in Ukraine. The main metrological characteristic of such a device is the ac/dc transfer difference, which problem have been solved by the leading national metrology institutes (NMI) around the world. The coordinator of the ILC was the Scientific and Production Institute of Metrological Support for Measurements of Electromagnetic Quantities of the SE "Ukrmetrteststandard", Kyiv. ILC was conducted for the radial scheme in accordance with the requirements of the program, developed by the specialists of SE "Ukrmetrteststandard", taking into account the requirements of international standards ISO/IEC 17025 [2], ISO/IEC 17043 and ISO 13528 [3].

\section{RELATED PAPERS}

Over the past three decades, due to the efforts of NMI researchers in many countries, uncertainty of measurement (UM) in the defining ac/dc transfer difference has been significantly reduced. In particular, during the key comparison CCEM-k6.a the leading NMIs achieved degrees of equivalence of national standards which are within the ranges from minus 0.6 to $0.4 \mu \mathrm{V} / \mathrm{V}$ at a frequency of $1 \mathrm{kHz}$ and from minus 23 to $27 \mu \mathrm{V} / \mathrm{V}$ at frequency of $1 \mathrm{MHz}$ [4]. In addition, the maximum value of the combined expanded UM for the assigned degree of equivalence was $100 \mu \mathrm{V} / \mathrm{V}$ at a frequency of $1 \mathrm{MHz}$ for NMI of South Korea, and the minimum value was less than $0.6 \mu \mathrm{V} / \mathrm{V}$ at a frequency of $1 \mathrm{kHz}$ for the NMI of Canada.

It should be noted that in the years 2013-2014, key comparison COOMET.EM-K6.a was held within the framework of the project of the regional metrological organization COOMET, in which five NMIs participated which represented Ukraine, Russia, Azerbaijan, Belarus and Romania. This comparison showed the degree of equivalence between national standards in the range from minus 30.6 to $25.8 \mu \mathrm{V} / \mathrm{V}$, and the corresponding combined expanded UMs ranged from 1.3 to $139 \mu \mathrm{V} / \mathrm{V}$ depending on the frequency [5]. It should be added that the Ukrainian national standard of the alternating voltage unit (DETU 08-07-02), which was applied to obtain the reference value of the ac/dc transfer difference in ILC, gained confirmation of its metrological characteristics and calibration and measurement capabilities during the last mentioned key comparison [6]. Thus, a link has been established between the global level of ILC of NMIs and the local level of ILC of the Ukrainian CLs.

The five CLs, which determined the metrological characteristics in accordance with their own procedures, participated in ILC, conducted under the coordination of the SE "Ukrmetrteststandard" in 2016-2017 [7]. According to the results of ILC, a minimum deviation of $6.2 \mu \mathrm{V} / \mathrm{V}$ at a frequency of $1 \mathrm{kHz}$ was achieved. It is important that the precision thermoconverter PNTE-6A was selected as a sample for testing CL qualification. A similar device was used as a travelling standard during the key comparison COOMET.EM-k6.a.

Concerning ILC of a local level in the field of the alternating voltage in the range up to $1000 \mathrm{~V}$, it is also worth noting bilateral ILC between the laboratory of electrical measurements of the Faculty of Engineering and Information Technologies at the Ss. Cyril and Methodius University in Skopje, and High Tech Test Shpk, Albania, in 2017. There, the Keysight 34401 A multimeter was used as a sample for testing in the alternating voltage range from 0.1 to $100 \mathrm{~V}$ [8]. The work was done to demonstrate the competence of both CLs according to ISO/IEC 17043.

\section{PROBLEM STATEMENT}

During the above mentioned ILC in Ukraine, all participants were required to provide information on: the name of the laboratory; date of measurement; equipment complex with which measurements were made; the value of air temperature, relative humidity and atmospheric pressure in the 
laboratory during the measurement; power supply parameters; description of the method and model of measurements and description of the measurement scheme; the value of the output thermo-emf for the selected frequencies; MRs and standard deviations of the ac/dc transfer difference; the uncertainty budget and the combined standard uncertainty of each MR. The participants of ILC had to give the above information as measurement protocols by the form provided in the annex to the ILC program.

The participants of ILC carried out measurements within 10-15 days and, upon completion, sent the PNTE-6A thermoconverter and the measurement protocol to ILC coordinator. After receiving the PNTE-6A thermoconverter from the ILC participant, the reference laboratory specialist repeatedly performed the measurement and determination of the standard deviation of the ac/dc transfer difference and the combined standard uncertainty of each MR at the selected frequencies. At the same time, the accuracy of MRs was evaluated for each $\mathrm{CL}$ as well as the analysis of the measurement protocol data was done.

According to the results of ILC, it was concluded that the competence level of the measuring laboratories, which confirmed their qualifications, had been good enough with some exceptions [9]. Considering the factors leading to the deviation of MRs obtained during ILC by various participants, the specialists of the SE "Ukrmetrteststandard" focused on several points. Firstly, the information on UM during the calibration of the PNTE-6A thermoconverter, given by one of CLs, showed exceeding relative to the similar figures of other participants. Secondly, the MRs in the protocol of this ILC participant differed significantly from the values of other participants, especially at a frequency of $100 \mathrm{kHz}$. Another negative point was the excess (in one of the points of observation at a frequency of $1 \mathrm{kHz}$ ) of the admissible value of the evaluation criterion for MR of another CL.

The article is a logical work development on the competence assessment of the ILC participants and analysis of peculiarities as well as aimed to distinguish the key factors that led to the above negative aspects in the overall ILC result.

\section{OVERVIEW OF THE INTERLABORATORY COMPARISON RESULTS}

The traveling thermoconverter PNTE-6A is the single junction thermal converter by the construction type. It manufactured as three-dimensional construction, in which the vacuum contact-free thermocouple was used. The short specification of this device is given bellow in Table 1 .

\section{Table 1}

\section{Main characteristics of thermoconverter} PNTE-6A

\begin{tabular}{lc}
\hline \hline Characteristic & Nominal \\
\hline Input voltage & $3 \mathrm{~V}$ \\
Output voltage & $5 \mathrm{mV}$ \\
Input resistance & $1000 \Omega$ \\
Output resistance & $20 \Omega$ \\
\hline \hline
\end{tabular}

The thermoconverter PNTE-6A has a squarelaw response of its output thermo-emf from the heater current.

The general form of the thermoconverter PNTE-6A is shown in Figure 1.

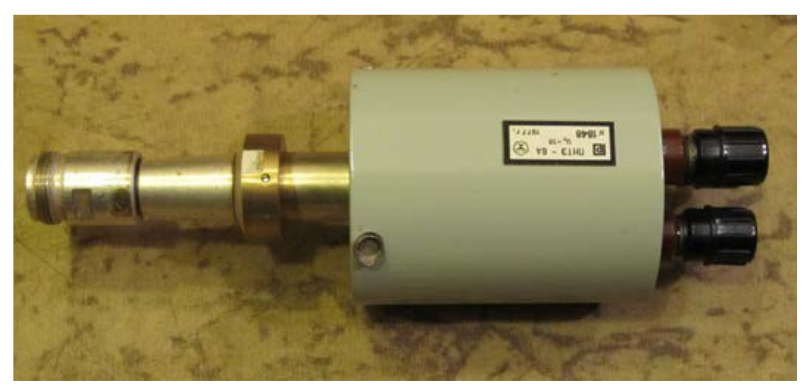

Fig. 1. General form of the thermoconverter PNTE-6A

Table 2 shows the UMs $U_{\text {lab }}$ which were reported by each CL during ILC depending on the input frequency.

T a b l e 2

\section{Uncertainty of measurement reported by ILC participants}

\begin{tabular}{cccccc}
\hline \hline $\begin{array}{c}\text { Code } \\
\text { of ILC par- } \\
\text { ticipant }\end{array}$ & $20 \mathrm{~Hz}$ & $1 \mathrm{kHz}$ & $20 \mathrm{kHz}$ & $100 \mathrm{kHz}$ & $1 \mathrm{MHz}$ \\
\hline Lab-1 & 65 & 59 & 65 & 95 & - \\
Lab-2 & 22 & 6 & 19 & 46 & 116 \\
Lab-3 & 48 & 8 & 28 & 79 & 203 \\
Lab-4 & 760 & 760 & 3140 & 3140 & - \\
\hline \hline
\end{tabular}


The data in Table 2 show a large difference in the UM levels of the first three ILC participants and the fourth laboratory.

The data evaluation results, which were provided by the CLs, are given in Table 3 . These data were processed by means of the modified criterion $E_{n}$ in accordance with the methodology set out in the report [9].

\section{T a b l e 3}

\section{Values of the criterion for evaluating the data of the ILC participants}

\begin{tabular}{cccccc}
\hline \hline $\begin{array}{c}\text { Code } \\
\text { of ILC par- } \\
\text { ticipant }\end{array}$ & $20 \mathrm{~Hz}$ & $1 \mathrm{kHz}$ & $20 \mathrm{kHz}$ & $100 \mathrm{kHz}$ & $1 \mathrm{MHz}$ \\
\hline Lab-1 & -0.86 & -0.45 & -0.64 & -0.15 & - \\
Lab-2 & 0.49 & 0.82 & 0.88 & 0.24 & 0.75 \\
Lab-3 & 0.45 & 1.52 & 0.99 & 0.13 & 0.38 \\
Lab-4 & -0.31 & -0.06 & 0.02 & 0.45 & - \\
\hline \hline
\end{tabular}

The data in Table 3 show the excess of the $E_{n}$ relating to the allowable value equal to 1 at frequency of $1 \mathrm{kHz}$ for Lab-3.

\section{MEASUREMENT SET-UP \\ AND UNCERTAINTY BUDGET OF STANDARDIZED PROCEDURE}

The factor that led to a large difference in UM of one of the laboratories, described in the previous section, was the use of equipment and method which differ from the recommendations of the normative document DSTU 7231 [10]. The second factor that led to the exceeding of the evaluation criterion for another CL was likely to be a mistake in the analysis of sources of uncertainty.

Returning to the reason for the deterioration of $\mathrm{UM}$, it is necessary to consider the uncertainty budgets for two variants of measuring circuit for calibrating the thermoconverter PNTE-6A. The first version of the measuring circuit is shown in Figure 2 and it represents the configuration of the measuring circuit in accordance with the calibration procedure that is corresponded with DSTU 7231, and is discribed in MKU 060-29/08 [11].

The measuring circuit is implemented for calibrating the voltage thermoconverter relative to the national standard of the alternating voltage unit from 0.1 to $1000 \mathrm{~V}$ in the frequency range from
$10 \mathrm{~Hz}$ to $1 \mathrm{MHz}$. In this case, the four voltage signals are applied in series to the inputs of the reference transfer standard Fluke $792 \mathrm{~A}$ and calibrated thermoconverter SJTC by means of two sources: ac - positive, dc - negative, dc - ac. The SA commutator of the voltage type switches the output signals of the direct voltage source (Source 1) and the alternating voltage source (Source 2), and the precision 8.5-digit voltage meters V2 and V3 are required to measure the output signal of single junction thermal converter (SJTC) and the Fluke $792 \mathrm{~A} \mathrm{ac} / \mathrm{dc}$ transfer standard. Voltage meter V1 is used to determine the value of the input signal.

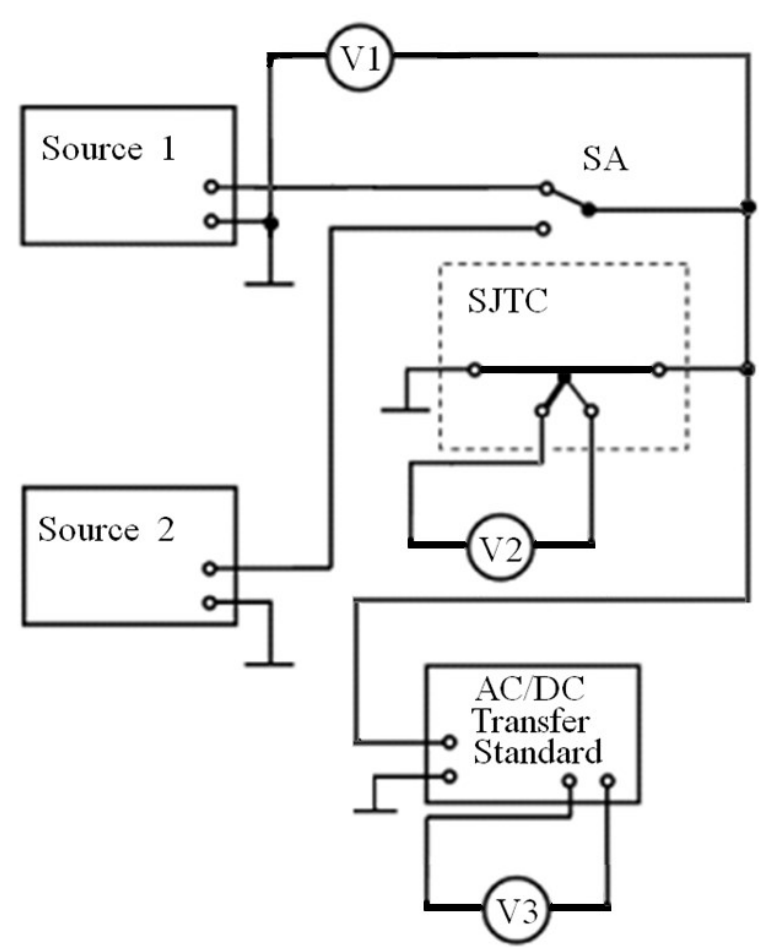

Fig. 2. Measurement set-up according to MKU 060-29/08

Calibration of PNTE-6A relative to DETU 0807-02 was carried out in accordance with the calibration procedure of the MKU 060-29/08 [11].

The measurement model for the single value of the ac/dc transfer difference of PNTE-6A $\gamma_{P N T E}$ looks like [12]:

$$
\gamma_{P N T E}=\gamma_{M R}-\delta_{792 A}-\Delta_{S},
$$

where

$\gamma_{M R}$ is uncorrected single value of the ac/dc transfer difference of PNTE-6A;

$\delta_{792 A}$ is the value of the correction of the Fluke $792 \mathrm{~A} \mathrm{ac} / \mathrm{dc}$ transfer standard given in the calibration certificate; 
$\Delta_{S}$ is a generalized parameter that takes into account the short-term instability of the Fluke 792A $\mathrm{ac} / \mathrm{dc}$ transfer standard, meters of the output thermoemf, direct and alternating voltage sources from the complement of the DETU 08-07-02.

The uncertainty budget is given in Table 4 according to the measurement model (1).

Table 4

The uncertainty budget according to the measurement model (1)

\begin{tabular}{|c|c|c|c|c|c|}
\hline$i$ & 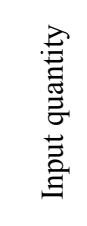 & 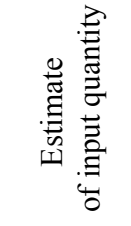 & 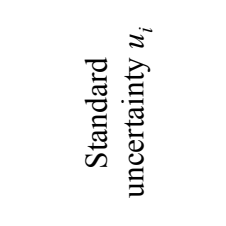 & 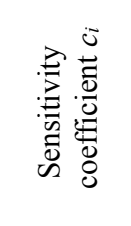 & 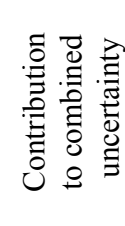 \\
\hline 1 & $\gamma_{M R}$ & $\bar{\gamma}_{M R}$ & $S_{M R}$ & 1 & $S_{M R}$ \\
\hline 2 & $\delta_{792 \mathrm{~A}}$ & $\hat{-}_{792 \mathrm{~A}}$ & $U_{792 \mathrm{~A}}$ & $U_{792 \mathrm{~A}}$ & $\frac{U_{792 A}}{2}$ \\
\hline 3 & $\Delta_{S}$ & $\bar{\Delta}_{s}$ & $S_{\Delta}$ & 1 & $S_{\Delta}$ \\
\hline & 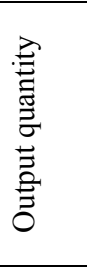 & 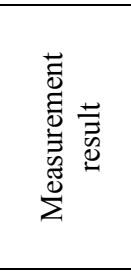 & 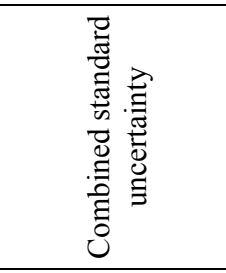 & 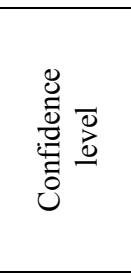 & 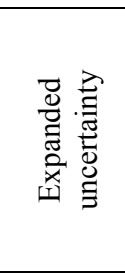 \\
\hline & NTE & $\begin{array}{c}\text { Equation } \\
\text { (1) }\end{array}$ & $u_{c o m b}=\sqrt{\sum_{m=1}^{3} c_{i}^{2} u_{i}^{2}}$ & $\begin{array}{c}k \approx 2, \\
\mathrm{P}=0.95\end{array}$ & $k \cdot i_{\text {comb }}$ \\
\hline
\end{tabular}

The following notations are used in Table 4:

$\bar{\gamma}_{M R}$ is the arithmetic mean of the uncorrected values of the ac/dc transfer difference of PNTE-6A calculated according to MKU 060-29/08;

$S_{M R}$ is standard deviation of $\bar{\gamma}_{M R}$ calculated according to MKU 060-29/08;

$\delta_{792 A}, \bar{\Delta}_{S}$ are the values of the correction of the Fluke 792A ac/dc transfer standard, and generalized parameter of the short-term instability of the DETU 08-07-02, respectively, evaluated by type B;

$U_{792 A}$ is the expanded uncertainty relatively to the use of the Fluke 792A ac/dc transfer standard;

$S_{\triangle}$ is standard deviation of the dissemination of the electric AC voltage unit from DETU 08-07-02 to PNTE-6A specified in the MKU 060-29/08.

\section{MEASUREMENT SET-UP AND UNCERTAINTY BUDGET OF ALTERNATIVE APPROACH}

The second version of the measuring circuit is shown in Figure 3 and it represents the configuration of the measuring circuit in accordance with the calibration procedure of Lab-4.

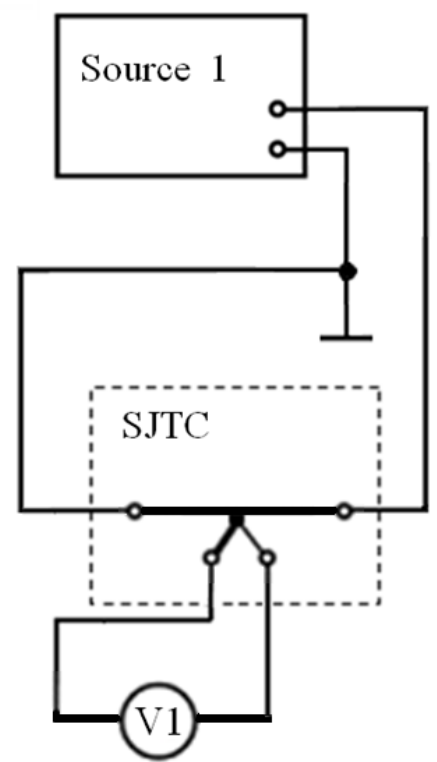

Fig. 3. Measurement set-up using a multifunction calibrator as a working standard

In this case, both the source of the direct and the alternating voltage are one and the same multifunction calibrator (Source 1) of electrical quantities which must have a calibration certificate indicating corrections and assosiated UMs. The values of the output signal of the SJTC thermoconverter for the ac and dc voltage of the calibrator output are measured with the help of a voltage meter V1. Regarding the measurement scheme, the uncertainty budget should be compiled in accordance with GUM 1995 [13] and should contain the input quantities given in Table 5, and the measurement model may be such:

$$
\begin{aligned}
\gamma_{P N T E}^{\prime} & =\frac{U_{A C}+\Delta_{A C}-3 \cdot \Delta U_{A C}}{U_{D C}+\Delta_{D C}-3 \cdot \Delta U_{D C}}- \\
& -\frac{E_{A C}-3 \cdot \Delta E}{2 \cdot\left(E_{D C}-3 \cdot \Delta E\right)}-\frac{1}{2},
\end{aligned},
$$

where

$U_{A C}, U_{D C}$ are uncorrected displays of a multifunction calibrator that is a working standard in the modes of reproduction of alternating voltage and direct voltage, respectively; 
$\Delta_{A C}, \Delta_{D C}$ are the values of the total corrections to the multifunction calibrator displays in the modes of reproduction of the alternating voltage and the dirtect voltage, respectively;

$\Delta U_{A C}, \Delta U_{D C}, \Delta E$ are drift of the output signal of the multifunction calibrator in the mode of an alternating voltage reproduction, its drift in the mode of a direct voltage reproduction and drift of the output thermo-emf of the thermal converter PNTE-6A, respectively;

$E_{A C}, E_{D C}$ are the output thermo-emf of the thermal converter PNTE-6A (according to the readout of a voltage meter) for the alternating voltage or direct voltage applied to it, respectively.

The following notations used in Table 5:

$$
\bar{U}_{A C}, \bar{U}_{D C}, \Delta \bar{U}_{A C}, \Delta \bar{U}_{D C}, \bar{E}_{A C}, \bar{E}_{D C}, \Delta \bar{E}
$$

are arithmetic mean of the multifunction calibrator displays in the mode of reproduction of the alternating voltage, its displays arithmetic mean in the mode of reproduction of the direct voltage, drift arithmetic mean of the output signals of this calibrator in the specified modes, the output arithmetic mean of the thermo-emf of the thermal converter PNTE-6A by the readout of the precision multimeter when the alternating voltage, and the direct voltage are apllied in series, and drift arithmetic mean of the output signal of the thermal converter PNTE-6A, respectively;

$$
S_{\bar{U}_{A C}}, S_{\bar{U}_{D C}}, S_{\Delta \bar{U}_{A C}}, S_{\Delta \bar{U}_{D C}}, S_{\bar{E}_{A C}}, S_{\bar{E}_{D C}}, S_{\Delta \bar{E}}
$$

are standard deviations of $U_{A C}, U_{D C}, \Delta U_{A C}, \Delta U_{D C}$, $E_{A C}, E_{D C}, \Delta E$, respectively, calculated in accordance with GUM 1995 [13];

$\vec{\Delta}_{A C}, \vec{\Delta}_{D C}$ are corrections to displays of a multifunction calibrator, estimated by type $\mathrm{B}$, in the reproduction of an alternating and a direct voltage, respectively;

$$
U_{\Delta_{A C}}, U_{\Delta_{D C}} \text { are type B standard uncertainties }
$$

in the reproduction of an alternating and a direct voltage, respectively.

As can be seen from Table 5, in order to determine correctly the ac/dc transfer difference of PNTE-6A, several corrective values to the measurement model (2) must be added these are the corrections to the displays of the working standard, the drift value of its output signal during the measurement (if it has a noticeable effect on the $\mathrm{MR}$ ), the drift value of the output thermo-emf of the calibrated thermoconverter.
Table 5

\begin{tabular}{|c|c|c|c|c|c|}
\hline$i$ & $\begin{array}{l}\text { 禀 } \\
\text { 壳 } \\
\text { 言 }\end{array}$ & 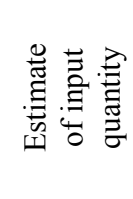 & 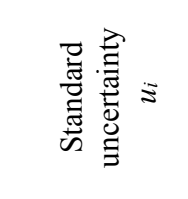 & 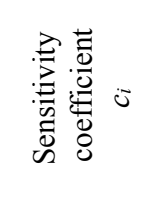 & 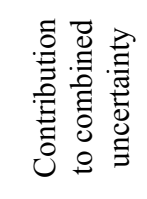 \\
\hline 1 & $U_{A C}$ & $\bar{U}_{A C}$ & $S_{U A C}$ & $\frac{\partial \gamma_{P N T E}^{\prime}}{\partial U_{A C}}$ & $\mathrm{c}_{1} \cdot \mathrm{S}_{\mathrm{UAC}}$ \\
\hline & $U_{D C}$ & $\bar{U}_{D C}$ & $S_{U D C}$ & $\frac{\partial \gamma_{P N T E}^{\prime}}{\partial U_{D C}}$ & $\mathrm{c}_{2} \cdot \mathrm{S}_{\mathrm{UDC}}$ \\
\hline 3 & $\Delta_{A C}$ & $\bar{\Delta}_{A C}$ & $u_{A C}$ & $\frac{\partial \gamma_{P N T E}^{\prime}}{\partial \Delta_{A C}}$ & $c_{3} \cdot u_{A C}$ \\
\hline 4 & $\Delta_{D C}$ & $\bar{\Delta}_{D C}$ & $u_{D C}$ & $\frac{\partial \gamma_{P N T E}^{\prime}}{\partial \Delta_{D C}}$ & $\mathrm{c}_{4} \cdot \mathrm{u}_{\mathrm{DC}}$ \\
\hline 5 & $\Delta U_{A C}$ & $\Delta \bar{U}_{A C}$ & $S_{\triangle U A C}$ & $\frac{\partial \gamma_{P N T E}^{\prime}}{\partial \Delta U_{A C}}$ & $\mathrm{c}_{5} \cdot \mathrm{S}_{\triangle \mathrm{UAC}}$ \\
\hline 6 & $\Delta U_{D C}$ & $\Delta \bar{U}_{D C}$ & $S_{\triangle U D C}$ & $\frac{\partial \gamma_{P N T E}^{\prime}}{\partial \Delta U_{D C}}$ & $\mathrm{c}_{6} \cdot \mathrm{S}_{\triangle \mathrm{UDC}}$ \\
\hline 7 & $E_{A C}$ & $\bar{E}_{A C}$ & $S_{E A C}$ & $\frac{\partial \gamma_{P N T E}^{\prime}}{\partial E_{A C}}$ & $\mathrm{c}_{7} \cdot \mathrm{S}_{\mathrm{EAC}}$ \\
\hline 8 & $E_{D C}$ & $\bar{E}_{D C}$ & $S_{E D C}$ & $\frac{\partial \gamma_{P N T E}^{\prime}}{\partial E_{D C}}$ & $\mathrm{c}_{8} \cdot \mathrm{S}_{\mathrm{EDC}}$ \\
\hline y & $\Delta E$ & $\Delta \bar{E}$ & $S_{\Delta E}$ & $\frac{\partial \gamma_{P N T E}^{\prime}}{\partial \Delta E}$ & $\mathrm{c}_{9} \cdot \mathrm{S}_{\Delta \mathrm{E}}$ \\
\hline & 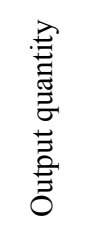 & 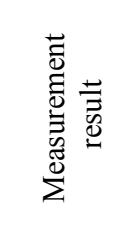 & 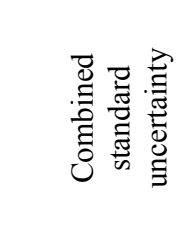 & 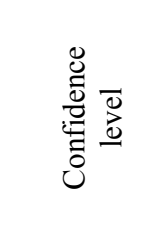 & 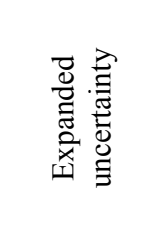 \\
\hline & $\gamma_{P N T E}^{\prime}$ & $\begin{array}{c}\text { Equation } \\
\text { (2) }\end{array}$ & $u_{c o m b}=\sqrt{ }$ & $\begin{array}{c}k \approx 2, \\
P=0.95\end{array}$ & $k \cdot u_{\mathrm{comb}}$ \\
\hline
\end{tabular}

The uncertainty budget according to the measurement model (2)

\section{RESULTS OF THE ANALYSIS}

As noted in the protocol of CL which used the non-standardized method for determining the ac/dc transfer difference, the values of UM were $760 \mu \mathrm{V} / \mathrm{V}$ for the lower frequencies range and $3140 \mu \mathrm{V} / \mathrm{V}$ for frequencies up to $100 \mathrm{kHz}$ [7]. It is known that specialists of the specified laboratory 
used the specification of the working standard due to the lack of a valid calibration certificate to evaluate UM. This fact indicates that there were no corrections to the multifunction calibrator displays and UM were excessive. It also follows from the laboratory report that the dynamic characteristics of the devices from the complex depicted in Fig. 3 were not taken into account (one of the ways for evaluating the drift of thermoelectric converters was described in detail in [14]). As a result, the MR deviations of this laboratory from the values of the reference laboratory, comparing with other participants, acquired significantly higher values, and the expanded uncertainties exceeded the UM of other participants in tens of times [9].

Another problem aspect of the competence testing of CLs was the exceeding the unit by the criterion for evaluating the ILC data for another participant, Lab-3, during the processing of the ILC results at a frequency of $1 \mathrm{kHz}$ (see Table 3 ). During the analysis, it was established that the reference thermoelectric converter, used as working standard, is periodically calibrated using the secondary standard of the AC voltage unit. Thus, there is a two-link connection between the specified working standard and DETU 08-07-02 which may lead to the accumulation of unconsidered uncertainty sources in the dissemination of the unit of physical quantity. In addition, the period from the previous calibration relative to the DETU 08-07-02 was unreasonably exceeded. Also, there was no information on the evaluation of the output thermo-emf drift of the working standard in the report of this ILC participant, indicating an understated value of UM.

\section{DISCUSSION}

The measurement of the ac/dc transfer difference may be implemented by any method and this is not prohibited by ISO/IEC 17043. In spite of this, the possibility of achieving the minimum possible values of UM occurs when certain requirements are met. One of them is the choice of measuring instrument with such metrological characteristic that its UM will not exceed the admissible contribution to the total UM. The key comparison of the world's leading laboratories [4] showed that the best UM values during the thermoconverter calibration can be achieved with the use of three main methods: method of differential measurement, 2-channel method, measuring method with help of a bridge scheme. All these methods are based on the use of a reference thermocomparator as a working standard.
To date, none of the NMIs have used the calibrator as a working standard, since only programmable impulse-controlled sources of the alternating voltage based on the Josephson standard allow to achieve UM at a level less than $1 \mu \mathrm{V} / \mathrm{V}$ [15].

Regarding the correctness of the application of the corrections and an adequate model of measurement, this aspect depends entirely on the experience of staff and familiarity with world developments.

\section{CONCLUSIONS}

The quality of measurement is in the maximum accuracy ensurance in the application of a certain complex of devices, timely verification of the state of these means, adequate determination of uncertainty sources as well as relevant documentary support etc.

In the ILC considered in the paper, one of the laboratories (Lab-3) made inadequat uncertainty budget that was reinforced, presumably, by the underestimation of the displacement of the metrological characteristics between two calibrations. These factors led to an exceeding of the permissible deviation value at $1 \mathrm{kHz}$.

The uncertainty budgets for the two variants of the measurement schemes allow UM to be adequately determined in measuring the ac/dc transfer difference in the CL conditions, and take into account the uncertainty sources that were not considered by one of the participants.

The use of working standard that had no definite actual metrological characeristics with an assosiated UM did not allow to determine the displacement of the ac/dc transfer difference. The same reason also did not allow to calculate correctly the metrological characeristic of the investigated PNTE-6A, including corrections as well as to calculate the total UM which would be significantly less for MRs of Lab-4.

\section{REFERENCES}

[1] Conformity assessment - General requirements for proficiency testing, ISO/IEC 17043, 2010.

[2] General requirements for the competence of testing and calibration laboratories, ISO/IEC 17025, 2005.

[3] Statistical methods for use in proficiency testing by interlaboratory comparison, ISO 13528, 2015.

[4] Klonz, Manfred: Key comparison of AC-DC voltage transfer standards at the lowest attainable level of uncertainty CCEM-K6.a. Final report, 2002. 
[5] Velychko, Oleh, Yu Darmenko: Final report on COOMET key comparison of $\mathrm{AC} / \mathrm{DC}$ voltage transfer references (COOMET. EM-K6. a), Metrologia, vol. 53, No. 1A (2016).

[6] Velychko, O.: International key comparison COOMET of National Standard of unit of AC voltage, Метрологія та прилади, vol. 63, No. 1, pp.11-19 (2017).

[7] Velychko, O., Isaiev, V.: Interlaboratory comparisons of calibration results of the precision electric voltage thermoconverter, Метрологія та прилади, vol. 68, №. 6, pp. 14-18 (2017).

[8] Čundeva-Blajer, M., Dimčev, V., Srbinovska, M., Gjergjani, G., Kuqi, D., Dollaku, E: Quality and confidence assurance in electrical quantities measurements-results of FEIT-HTT inter-laboratory comparison, Journal of Electrical Engineering and Information Technologies (JEEIT), vol. 2, No.1, pp. 15-23 (2017).

[9] Velychko, O., Anokhin, Yu, Isaiev, V.: Report on interlaboratory comparison conducting of measurement results in calibration of precision thermoconverter PNTE-6A in accordance with requirements of ISO/IEC 17025, SE Ukrmetrteststandard, 2017.
[10] Metrology. Thermoelectric reference converters and comparators. Verification method (calibration), DSTU 7231 (2011).

[11] Metrology. Voltage measuring converters. Method of calibration, SE Ukrmetrteststandard, MKU 060-29/08 (2011).

[12] Velychko, O., Isaiev, V.: Research of metrological characteristic of the state primary standard of the unit electric variable voltage, Метрологія та прилади, vol. 67, №. 5 , pp. 13-19 (2017).

[13] Evaluation of measurement data - Guide for the expression of uncertainty in measurement, BIPM, IEC, et al., JCGM 100 (2008)

[14] Velychko, O., Isaiev, V.: Evaluation of the influence of some dynamic characteristics during the calibration of precision thermal converters, Збірник наукових праць Одеської державної академії̈ технічного регулювання та якості, vol. 11, №. 2, pp. 39-45 (2017).

[15] Budovsky, I., Georgakopoulos, D., Hagen, T., Sasaki, H., Yamamori, H.: Precision AC-DC difference measurement system based on a programmable Josephson voltage standard, IEEE Transactions on Instrumentation and Measurement, vol. 60, No. 7, pp. 2439-2444 (2011). 